\title{
Neck Circumference as a Simple Screening Measure for Identifying Egyptian Overweight and Obese Adults
}

\author{
Azza Sarry El Din, Nayera Hassan, Sahar El-Masry*, Muhammad Al-Tohamy \\ National Research Centre, Biological Anthropology, ElBuhose street, Dokki, Giza, Cairo 12622, Egypt
}

\author{
Citation: Sarry EI Din A, Hassan N, El-Masry S, \\ Al-Tohamy M. Neck Circumference as a Simple \\ Screening Measure for Identifying Egyptian \\ Overweight and Obese Adults. Maced $\mathrm{J}$ Med \\ Sci. $2013 \quad$ Sep 15; 6(3):232-237. \\ http://dx.doi.org/10.3889/MJMS.1857-5773.2013.0309. \\ Key words: Neck circumference; \\ Anthropometry; overweight; obesity; adults. \\ "Correspondence: Prof. Sahar Abd El-Raufe \\ El-Masry. National Research Centre, Biological \\ Anthropology, National Research Centre \\ Bohooth St., Dokki, Giza, Cairo 12622, Egypt. \\ Phone: 0106606640 . \\ E-Mail: masrysa@yahoo.com \\ Received: 11-Jun-2013; Revised: 28-Jul- \\ 2013; Accepted: 17-Jul-2013; Online first: \\ 04-Sep-2013 \\ Copyright: @ 2013 Sarry El Din A. This is an \\ open-access article distributed under the terms \\ of the Creative Commons Attribution License, \\ which permits unrestricted use, distribution, \\ and reproduction in any medium, provided the \\ original author and source are credited. \\ Competing Interests: The authors have \\ declared that no competing interests exist.
}

\begin{abstract}
Background: Neck circumference (NC) is a simple screening measure for identifying overweight and obesity.

Aims: To determine whether a single measure of NC might be used to identify overweight and obesity, and to define NC cutoff levels for Egyptian overweight and obesity according to existing BMI and WC cutoff levels.

Settings and Design: A prospective cross-sectional study from upper and lower Egypt.

Materials and Methods: Main indicators included NC, weight, height, waist and hip circumferences (WC) and body mass index (BMI).

Results: Pearson's correlation indicated a significant positive association between changes in NC and changes in body mass index and WC in both men and women. ROC analysis showed that the area under the curve (AUC) for $\mathrm{NC}$ and $\mathrm{BMI}>25 \mathrm{~kg} / \mathrm{m}^{2}$ was 0.80 for men, 0.69 for women, respectively, while that for $\mathrm{BMl}>30 \mathrm{~kg} / \mathrm{m}^{2}$ was 0.88 for men, 0.75 for women, respectively. $\mathrm{NC} \geq 38$ $\mathrm{cm}$ for men and $\geq 36 \mathrm{~cm}$ for women were the best cut-off points for determining subjects with overweight.
\end{abstract}

Conclusion: NC measurement is simple and timesaving screening measure that can be used to identify overweight and obesity. Patients with $\mathrm{NC}>38 \mathrm{~cm}$ for men and $>36 \mathrm{~cm}$ for women require additional evaluation of overweight or obesity.

\section{Introduction}

Body mass Index (BMI) is a traditional measure of obesity, and individuals with values between 25 and $29.9 \mathrm{~kg} / \mathrm{m}^{2}$ are considered as being overweight while those with values of $30 \mathrm{~kg} / \mathrm{m}^{2}$ or higher as obese according to Expert Panel on the Identification, Evaluation, and Treatment of Overweight in Adults [1].

Egypt Demographic and Health Survey [2] stated that the proportion classified as obese increased from 6 percent among men aged 15-19 to 33 percent of men aged 55-59. Urban men were much more likely than rural men to be obese (22 percent and 15 percent, respectively). The proportions classified as obese increased directly with age, from a level of 10 percent among women aged $15-19$ to 65 percent or more among women in the 45-59 age groups. Urban women were more likely to be obese than rural women, and the percentage classified as obese ranged from 25 percent in rural Upper Egypt to 49 percent in the urban Lower Egypt.

There are numerous methods of assessing overweight and obesity. Some techniques are applicable at primary care facilities, such as measurements of weight, height, waist and hip circumferences, and calculations of waist/ hip ratio and BMI. It is not always practical to use these techniques, especially in winter, in busy, everyday primary care practice. Other procedures, such as ultrasound, computed tomography and magnetic 
resonance imaging are expensive and are primarily used for research purposes. As a first step to achieve obesity control, it is important to develop a reliable, simple, quick method for the assessment of obesity in primary care clinics [3].

Vague [4] was the first researcher to realize that different body morphology or types of fat distribution are related to the health risks associated with obesity. He used a neck skin fold in his index of masculine differentiation to assess upper-body fat distribution.

Although obesity results in metabolic abnormalities, upper-body obesity is more strongly associated with glucose intolerance, hyperinsulineamia, diabetes, hypertriglyceridemia, gout, and uric calculous disease than is lower-body obesity [5]. Neck circumference as an index of upperbody subcutaneous adipose tissue distribution, was evaluated in relation to cardiovascular risk factors [6]. In addition, relationships were examined between changes in body composition, including the neck size, and changes in cardiovascular risk factors [7]. Furthermore, the free fatty acid release from upper body subcutaneous fat was found to be larger than that from lower-body subcutaneous fat [8], a fact that further strengthens the relevance of measuring upperbody subcutaneous adipose tissue depots. These observations indicate that NC as an index of upper body fat distribution can be used to identify overweight and obese patients.

The aim of this study was to determine whether a single measure of NC might be used to identify overweight and obese adults and to define NC cutoff levels for overweight and obesity according to existing BMI and waist circumference cutoff levels; as standards for general and central obesity respectively.

\section{Subjects and Methods}

This study was derived from a communitybased cross-sectional survey for establishing comprehensive anthropometric measurements for the dimensions of the Egyptian human body to be used for obtaining the standards needed for the Egyptian clothing industry (Science Technology Development Fund; STDF; Basic Research, no.1256). The present study included 6718 adult Egyptian subjects of both sexes (2926 men and 3792 women) with age range 21-55 years old. They were representing different geographic localities and different social classes. The sample was taken from the Greater Cairo, Alexandria and EI Mehala cities; representing lower Egypt; El Fayoum, Bany Souif and El Menia cities representing upper Egypt. The survey included subjects working in governmental organizations, factories, and attending social clubs. Informed written consent was obtained from the participants. The experimental design was approved from an ethical and scientific standpoint, by the ethical committee board of the National Research

\section{Centre of Egypt (No.09/038).}

Anthropometric evaluation was performed. The height, weight, waist, hip and neck circumferences were measured following the recommendations of the International Biological Program [9]. The height was measured to the nearest $0.1 \mathrm{~cm}$ using a fixed stadiometer (Seca), and the weight was determined to the nearest $0.01 \mathrm{~kg}$ using a Seca Scale Balance, with the subject wearing minimal clothing and no shoes. Waist circumference was measured at the midpoint between the lower rib margin and the iliac crest with the subject standing at the end of normal expiration, hip circumference at the level of the iliac crest, neck circumference (NC) in the midway of the neck ( between midcervical spine and midanterior neck), using non-stretchable plastic tape to the nearest $0.1 \mathrm{~cm}$. In men with a laryngeal prominence (Adam's apple), NC was measured just below the prominence. All circumferences were taken with the subjects standing upright, with the face directed forward and shoulders relaxed. The following adiposity indices were calculated: Body mass index (BMI): as weight (in kilograms) divided by height (in meters) squared and Waist/ Hip ratio $(\mathrm{cm} / \mathrm{cm})$.

\section{Definitions}

Normal BMI was defined as less than 25 $\mathrm{kg} / \mathrm{m}^{2}$, overweight as BMI $\geq 25 \mathrm{~kg} / \mathrm{m}^{2}$ and obesity as $\mathrm{BMI} \geq 30 \mathrm{~kg} / \mathrm{m}^{2}$ for both men and women[1]. None of the present sample had morbid obesity (BMI $\geq 40$ $\mathrm{kg} / \mathrm{m}^{2}$ ). Waist circumference was defined as normal up to $94 \mathrm{~cm}$ for men and $80 \mathrm{~cm}$ for women [10]. High waist circumference was defined at two levels as described previously [10], with slight changes, as 94 to $102 \mathrm{~cm}$ for men and 80 to $88 \mathrm{~cm}$ for women as overweight, or $102 \mathrm{~cm}$ for men and $88 \mathrm{~cm}$ for women as obese. Waist: hip ratio cut off was defined as equal or more than 0.95 for overweight men and 0.80 for overweight women [10-13]. True-positive subjects were those with high BMI and high NC. True-negative subjects were those with low BMI and low NC. Falsepositive subjects were those with high NC and low BMI. False-negative subjects were those with low NC and high BMI. Sensitivity was calculated as truepositives/ (true-positives + false-negatives); specificity as true negatives/ (true-negatives + false-positives). Positive predictive value (PPV) was defined as the percentage of subjects with high BMl who had high NC. Negative predictive value (NPV) was defined as the percentage of subjects with low BMI who had low NC.

\section{Statistical Analysis}

The significance of sex differences in the anthropometric parameters was tested by using the student t-test. Pearson's correlations between NC and various variables by sex were done. All tests of significance were two-tailed. To find the optimal, 
maximal sensitivity and specificity for $\mathrm{NC}$, the receiver output curve (ROC) analysis of cutoff points at intervals of 0.5 or $1 \mathrm{~cm}$ for $\mathrm{NC}$ against two levels of BMI was performed. Maximal accuracy and PPV/NPV closest to 1 were used for cutoff level determination. $P$ value of 0.05 was considered significant. Data were analyzed using the SPSS computer program, version 16.0 .

\section{Results}

There is insignificant sex difference in the mean age. However, Men were highly significant heavier, taller, and had larger WC, NC and waist: hip ratio than the women in this sample, while women had highly significant higher values of BMI and hip circumference (Table1).

Table 1: Characteristics of the sample by sex(using t-test).

\begin{tabular}{|c|c|c|c|c|c|c|c|}
\hline & \multicolumn{3}{|c|}{ MEN } & \multicolumn{3}{|c|}{ Women } & \multirow[t]{2}{*}{$P$} \\
\hline & $\mathrm{N}$ & Mean & SD & $\mathrm{N}$ & Mean & SD & \\
\hline $\begin{array}{l}\text { Age } \\
\text { (years) }\end{array}$ & 2926 & 36.44 & 9.27 & 3792 & 36.82 & 10.19 & 0.110 \\
\hline Wt (Kg) & 2705 & 83.7272 & 16.0952 & 3529 & 78.1515 & 16.0448 & 0.000 \\
\hline $\mathrm{Ht}(\mathrm{cm})$ & 2914 & 171.6670 & 6.9779 & 3788 & 159.2735 & 6.1852 & 0.000 \\
\hline$W C(\mathrm{~cm})$ & 2907 & 97.9219 & 13.8160 & 3786 & 94.2140 & 13.9991 & 0.000 \\
\hline Hip C & 2788 & 106.5725 & 19.1641 & 3783 & 113.5214 & 12.3792 & 0.000 \\
\hline $\mathrm{NC}(\mathrm{cm})$ & 2910 & 40.8412 & 3.9319 & 3782 & 39.5308 & 5.1329 & 0.000 \\
\hline $\begin{array}{l}\mathrm{BMI} \\
\left(\mathrm{Kg} / \mathrm{m}^{2}\right)\end{array}$ & 2703 & 28.3195 & 4.9340 & 3528 & 30.8307 & 6.1925 & 0.000 \\
\hline $\begin{array}{l}\text { Waist/Hip } \\
\text { ratio } \\
(\mathrm{cm} / \mathrm{cm})\end{array}$ & 2785 & 0.9254 & 0.2275 & 3780 & 0.8296 & 0.087 & 0.000 \\
\hline
\end{tabular}

In bivariate analysis, a strong correlation was found between NC and age, weight, height, waist and hip circumferences, BMI and waist: hip ratio for men and women ( $p, 0.0001)$ (Table 2). The strongest correlation was found between $\mathrm{NC}$ and $\mathrm{BMI}\left(\mathrm{R}^{2}=0.59\right.$ for men and 0.42 for women), followed by WC $\left(R^{2}=\right.$ 0.54 for men and 0.37 for women). While the correlation between $\mathrm{NC}$ and waist/ hip ratio was very low $\left(R^{2}=0.12\right.$ for men and 0.15 for women). So, the recommended cut off points for BMI and WC only were used as standards to predict the NC cut off points.

Table 2: Pearson's correlations between NC and various variables and their statistical significance by sex.

\begin{tabular}{|c|c|c|c|c|}
\hline \multirow{3}{*}{ Variables } & \multicolumn{4}{|c|}{$\mathrm{NC}$} \\
\hline & \multicolumn{2}{|c|}{$\begin{array}{c}\text { Men } \\
(n=2910)\end{array}$} & \multicolumn{2}{|c|}{$\begin{array}{c}\text { Women } \\
(n=3782)\end{array}$} \\
\hline & $\mathrm{r}$ & $p$ & $\mathrm{r}$ & $\mathrm{p}$ \\
\hline Age (years) & $0.242^{* \star}$ & 0.000 & $0.231^{* *}$ & 0.000 \\
\hline Wt $(\mathrm{Kg})$ & $0.573^{\star *}$ & 0.000 & $0.424^{* *}$ & 0.000 \\
\hline $\mathrm{Ht}(\mathrm{cm})$ & $0.080^{\star *}$ & 0.000 & $0.041^{* *}$ & 0.000 \\
\hline WC $(\mathrm{cm})$ & $0.538^{\star \star}$ & 0.000 & $0.369^{* *}$ & 0.000 \\
\hline Hip C (cm) & $0.273^{\star *}$ & 0.000 & $0.362^{* *}$ & 0.000 \\
\hline $\mathrm{BMI}\left(\mathrm{Kg} / \mathrm{m}^{2}\right)$ & $0.587^{\star *}$ & 0.000 & $0.420^{* *}$ & 0.000 \\
\hline Waist $/$ Hip ratio $(\mathrm{cm} / \mathrm{cm})$ & $0.119^{* *}$ & 0.000 & $0.151^{\text {**}}$ & 0.000 \\
\hline
\end{tabular}

NC $38.25 \mathrm{~cm}$ for men and $36.25 \mathrm{~cm}$ for women were the best cutoff levels for determining the overweight subjects with BMI $\geq 25 \mathrm{~kg} / \mathrm{m}^{2}$, using ROC analysis with $83 \%$ sensitivity, $60 \%$ specificity, 0.86
PPV/NPV, and $72 \%$ accuracy for men, and $76 \%$ sensitivity, 55\% specificity,0.90 PPV/NPV, and 65\% accuracy for women (Table 3, 4).

Table 3: Neck Circumference (cm) cutoff levels for determining the overweight and obese men $\left(B M I \geq 25\right.$ and $\left.\geq 30 \mathrm{Kg} / \mathrm{m}^{2}\right)$ using ROC analysis.

\begin{tabular}{|c|c|c|c|c|c|c|c|c|}
\hline \multirow{3}{*}{$\begin{array}{l}\text { Cutoff } \\
\text { Level } \\
(\mathrm{cm})\end{array}$} & \multicolumn{8}{|c|}{ Men } \\
\hline & \multicolumn{4}{|c|}{ Overweight } & \multicolumn{4}{|c|}{ Obese } \\
\hline & $\begin{array}{l}\text { Sen- } \\
\text { sitivity } \\
(\%)\end{array}$ & $\begin{array}{c}1- \\
\text { Spe- } \\
\text { cificity } \\
(\%)\end{array}$ & $\begin{array}{l}\text { PPVI } \\
\text { NPV }\end{array}$ & $\begin{array}{c}\text { Accu- } \\
\text { racy } \\
(\%)\end{array}$ & $\begin{array}{c}\text { Sen- } \\
\text { sitivity } \\
(\%)\end{array}$ & $\begin{array}{c}1- \\
\text { Spe- } \\
\text { cificity } \\
(\%)\end{array}$ & $\begin{array}{l}\text { PPVI } \\
\text { NPV }\end{array}$ & $\begin{array}{c}\text { Accu- } \\
\text { racy } \\
(\%)\end{array}$ \\
\hline 30.5 & 100 & 100 & 0.50 & 50 & 100 & 100 & 0.50 & 50 \\
\hline 31.5 & 100 & 100 & 0.50 & 50 & 100 & 100 & 0.50 & 50 \\
\hline 32.5 & 100 & 99 & 0.50 & 51 & 100 & 99 & 0.50 & 51 \\
\hline 33.5 & 100 & 97 & 0.54 & 51 & 100 & 97 & 0.51 & 51 \\
\hline 34.5 & 100 & 93 & 0.55 & 53 & 100 & 93 & 0.53 & 54 \\
\hline 35.5 & 99 & 83 & 0.58 & 58 & 99 & 83 & 0.57 & 58 \\
\hline 36.5 & 97 & 71 & 0.64 & 63 & 99 & 71 & 0.61 & 64 \\
\hline 37.75 & 93 & 55 & 0.73 & 69 & 97 & 55 & 0.68 & 71 \\
\hline 38.25 & 83 & 40 & 0.86 & 72 & 94 & 40 & 0.77 & 77 \\
\hline 38.75 & 83 & 40 & 0.87 & 72 & 94 & 40 & 0.77 & 77 \\
\hline 39.25 & 71 & 28 & 1.01 & 72 & 87 & 28 & 0.89 & 80 \\
\hline 39.75 & 71 & 28 & 1.01 & 72 & 87 & 28 & 0.89 & 80 \\
\hline 40.25 & 59 & 17 & 1.16 & 71 & 79 & 17 & 1.03 & 81 \\
\hline 40.75 & 59 & 17 & 1.16 & 71 & 78 & 17 & 1.04 & 80 \\
\hline 41.5 & 48 & 11 & 1.29 & 69 & 69 & 11 & 1.17 & 79 \\
\hline 42.5 & 35 & 7 & 1.41 & 64 & 54 & 7 & 1.32 & 73 \\
\hline 43.5 & 26 & 5 & 1.51 & 61 & 43 & 5 & 1.44 & 69 \\
\hline 44.5 & 18 & 3 & 1.60 & 58 & 31 & 3 & 1.57 & 64 \\
\hline 45.5 & 13 & 2 & 1.64 & 55 & 22 & 2 & 1.65 & 60 \\
\hline 46.5 & 8 & 2 & 1.59 & 53 & 14 & 2 & 1.68 & 56 \\
\hline 47.5 & 5 & 1 & 1.59 & 52 & 10 & 1 & 1.70 & 54 \\
\hline 48.5 & 3 & 1 & 1.51 & 51 & 5 & 1 & 1.68 & 52 \\
\hline 49.5 & 1 & 1 & 1.26 & 50 & 2 & 1 & 1.52 & 51 \\
\hline 50.5 & 1 & 1 & 1.11 & 50 & 2 & 1 & 1.39 & 50 \\
\hline 51.5 & 1 & 1 & 1.10 & 50 & 1 & 1 & 1.40 & 50 \\
\hline 52.5 & 1 & 1 & 0.99 & 50 & 1 & 1 & 1.28 & 50 \\
\hline 53.5 & 0 & 0 & 0.79 & 50 & 1 & 0 & 1.09 & 50 \\
\hline 54.5 & 0 & 0 & 0.79 & 50 & 0 & 0 & 1.18 & 50 \\
\hline 55.5 & 0 & 0 & 0.66 & 50 & 0 & 0 & 1.04 & 50 \\
\hline 56.5 & 0 & 0 & 0.49 & 50 & 0 & 0 & 0.84 & 50 \\
\hline
\end{tabular}

While NC $40.25 \mathrm{~cm}$ for men and $37.25 \mathrm{~cm}$ for women were the best cutoff levels for determining obese subjects with BMI $\geq 30.0 \mathrm{~kg} / \mathrm{m}^{2}$ using ROC analysis, with $79 \%$ sensitivity, $83 \%$ specificity, 1.03 PPV/NPV, and $81 \%$ accuracy were found for men and $79 \%$ sensitivity, $63 \%$ specificity, 0.91 PPV/NPT, and $71 \%$ accuracy for women (Table 3,4 ).

Table 4: Neck Circumference $(\mathrm{cm})$ cutoff levels for determining the overweight and obese women (BMI $\geq 25$ and $\left.\geq 30 \mathrm{Kg} / \mathrm{m}^{2}\right)$ using ROC analysis.

\begin{tabular}{ccccc|cccc}
\hline & \multicolumn{9}{c}{ Women } \\
\cline { 2 - 9 } $\begin{array}{c}\text { Level } \\
\text { (cm) }\end{array}$ & $\begin{array}{c}\text { Onerweight } \\
\text { Sitivity } \\
(\%)\end{array}$ & $\begin{array}{c}1- \\
\text { Speci- } \\
\text { ficity } \\
(\%)\end{array}$ & NPVI & $\begin{array}{c}\text { Accu- } \\
\text { racy } \\
(\%)\end{array}$ & $\begin{array}{c}\text { Sen- } \\
\text { sitivity } \\
(\%)\end{array}$ & $\begin{array}{c}1- \\
\text { Speci- } \\
\text { ficity } \\
(\%)\end{array}$ & $\begin{array}{c}\text { PPVI } \\
\text { NPV }\end{array}$ & $\begin{array}{c}\text { Accu- } \\
\text { racy } \\
(\%)\end{array}$ \\
\hline 30.5 & 100 & 97 & 0.54 & 51 & 100 & 97 & 0.52 & 51 \\
31.5 & 99 & 92 & 0.56 & 54 & 100 & 92 & 0.53 & 54 \\
32.5 & 97 & 83 & 0.65 & 57 & 99 & 83 & 0.58 & 58 \\
33.5 & 93 & 69 & 0.71 & 62 & 97 & 69 & 0.64 & 64 \\
34.5 & 88 & 61 & 0.78 & 63 & 95 & 61 & 0.69 & 67 \\
35.5 & 81 & 54 & 0.85 & 64 & 90 & 54 & 0.76 & 68 \\
36.25 & 76 & 45 & 0.90 & 65 & 86 & 45 & 0.82 & 70 \\
36.75 & 75 & 45 & 0.91 & 65 & 85 & 45 & 0.83 & 70 \\
37.25 & 68 & 37 & 0.98 & 65 & 79 & 37 & 0.91 & 71 \\
37.75 & 67 & 37 & 0.98 & 65 & 79 & 37 & 0.91 & 71 \\
38.25 & 57 & 30 & 1.06 & 64 & 68 & 30 & 1.01 & 69 \\
39.25 & 47 & 24 & 1.13 & 62 & 56 & 24 & 1.11 & 66 \\
40.25 & 38 & 19 & 1.17 & 59 & 45 & 19 & 1.18 & 63 \\
40.75 & 37 & 19 & 1.17 & 59 & 45 & 19 & 1.18 & 63 \\
41.5 & 32 & 16 & 1.21 & 58 & 39 & 16 & 1.23 & 61 \\
42.5 & 25 & 12 & 1.24 & 56 & 31 & 12 & 1.28 & 59 \\
43.5 & 20 & 10 & 1.24 & 55 & 25 & 10 & 1.30 & 57 \\
44.5 & 16 & 8 & 1.29 & 54 & 20 & 8 & 1.34 & 56 \\
45.5 & 13 & 6 & 1.32 & 53 & 16 & 6 & 1.39 & 55 \\
46.5 & 9 & 4 & 1.32 & 52 & 12 & 4 & 1.40 & 54 \\
47.5 & 6 & 3 & 1.33 & 52 & 8 & 3 & 1.42 & 53 \\
48.5 & 4 & 2 & 1.35 & 51 & 5 & 2 & 1.45 & 52 \\
49.5 & 3 & 1 & 1.42 & 51 & 4 & 1 & 1.51 & 51 \\
50.5 & 2 & 1 & 1.36 & 51 & 3 & 1 & 1.45 & 51 \\
51.5 & 1 & 1 & 1.25 & 50 & 2 & 1 & 1.36 & 50 \\
52.5 & 1 & 1 & 1.27 & 50 & 1 & 1 & 1.38 & 50 \\
53.5 & 0 & 0 & 2.00 & 50 & 1 & 0 & 1.99 & 50 \\
\hline & & & & & & & &
\end{tabular}


Table 5: Neck Circumference (cm) cutoff levels for determining the overweight and obese men (WC $\geq 94$ and $\geq 102 \mathrm{Kg} / \mathrm{m}^{2}$ ) using ROC analysis.

\begin{tabular}{ccccc|cccc}
\hline \multirow{3}{*}{$\begin{array}{c}\text { Cutoff } \\
\text { Level }\end{array}$} & \multicolumn{9}{c}{ Overweight } & \multicolumn{6}{c}{ Onen } \\
\cline { 2 - 8 }$(\mathrm{cm})$ & $\begin{array}{c}\text { Sen- } \\
\text { sitivity } \\
(\%)\end{array}$ & $\begin{array}{c}1- \\
\text { Speci- } \\
\text { ficity } \\
(\%)\end{array}$ & PPVI & $\begin{array}{c}\text { Accu- } \\
\text { racy } \\
(\%)\end{array}$ & $\begin{array}{c}\text { Sen- } \\
\text { sitivity } \\
(\%)\end{array}$ & $\begin{array}{c}1- \\
\text { Speci- } \\
\text { ficity } \\
(\%)\end{array}$ & $\begin{array}{c}\text { PPVI } \\
\text { NPV }\end{array}$ & $\begin{array}{c}\text { Accu- } \\
\text { racy } \\
(\%)\end{array}$ \\
\hline 30.5 & 100 & 100 & 0.68 & 50 & 100 & 100 & 0.50 & 50 \\
31.5 & 100 & 99 & 0.62 & 50 & 100 & 99 & 0.50 & 50 \\
32.5 & 100 & 99 & 0.56 & 51 & 100 & 99 & 0.50 & 51 \\
33.5 & 100 & 97 & 0.56 & 51 & 100 & 97 & 0.51 & 51 \\
34.5 & 99 & 94 & 0.58 & 52 & 100 & 94 & 0.54 & 53 \\
35.5 & 98 & 88 & 0.60 & 55 & 100 & 88 & 0.55 & 56 \\
36.5 & 96 & 77 & 0.65 & 59 & 99 & 77 & 0.59 & 61 \\
37.5 & 91 & 63 & 0.73 & 64 & 97 & 63 & 0.65 & 67 \\
37.75 & 91 & 63 & 0.73 & 64 & 97 & 63 & 0.65 & 67 \\
38.25 & 75 & 48 & 0.90 & 64 & 94 & 48 & 0.74 & 73 \\
38.75 & 75 & 48 & 0.90 & 64 & 94 & 48 & 0.74 & 73 \\
39.25 & 60 & 35 & 1.02 & 62 & 86 & 35 & 0.86 & 76 \\
39.75 & 59 & 35 & 1.02 & 62 & 86 & 35 & 0.86 & 76 \\
40.5 & 44 & 23 & 1.13 & 60 & 76 & 23 & 1.00 & 77 \\
41.5 & 32 & 17 & 1.20 & 58 & 66 & 17 & 1.13 & 75 \\
42.5 & 20 & 11 & 1.24 & 55 & 51 & 11 & 1.28 & 70 \\
43.5 & 14 & 8 & 1.24 & 53 & 40 & 8 & 1.38 & 66 \\
44.5 & 9 & 6 & 1.19 & 52 & 29 & 6 & 1.47 & 62 \\
45.5 & 5 & 3 & 1.26 & 51 & 21 & 3 & 1.61 & 59 \\
46.5 & 2 & 2 & 1.03 & 50 & 13 & 2 & 1.64 & 56 \\
47.5 & 1 & 1 & 0.95 & 50 & 9 & 1 & 1.68 & 54 \\
48.5 & 1 & 1 & 0.74 & 50 & 5 & 1 & 1.60 & 52 \\
49.5 & 0 & 1 & 0.59 & 50 & 2 & 1 & 1.43 & 51 \\
50.5 & 0 & 0 & 0.72 & 50 & 2 & 0 & 1.55 & 51 \\
52 & 0 & 0 & 0.44 & 50 & 1 & 0 & 1.34 & 50 \\
53.5 & 0 & 0 & 0.64 & 50 & 1 & 0 & 1.29 & 50 \\
\hline
\end{tabular}

Using WC as standard for classification of overweight and obesity (WC > 94 and $102 \mathrm{~cm}$ for men and $>80 \mathrm{~cm}$ and $88 \mathrm{~cm}$ for women respectively), the cutoff points of NC were found to be $38.25 \mathrm{~cm}$ for overweight and $40.5 \mathrm{~cm}$ for obese men. Using ROC analysis with $75 \%$ sensitivity, $52 \%$ specificity, 0.90 PPV/NPV, and 64\% accuracy for overweight men, and $76 \%$ sensitivity, $77 \%$ specificity, $1.00 \mathrm{PPV} / \mathrm{NPV}$, and $77 \%$ accuracy for obese men were found (Table 5). While the best cut off points of NC for obese women was $37.25 \mathrm{~cm}$ with $76 \%$ sensitivity, $58 \%$ specificity, $0.91 \mathrm{PPV} / \mathrm{NPV}$, and $67 \%$ accuracy. ROC curve could not predict certain cut off value for the overweight women (Table 6).

Table 6: Neck Circumference $(\mathrm{cm})$ cutoff levels for determining the overweight and obese women (WC $\geq 80$ and $\geq 88 \mathrm{Kg} / \mathrm{m}^{2}$ ) using ROC analysis.

\begin{tabular}{|c|c|c|c|c|c|c|c|c|}
\hline \multirow{3}{*}{$\begin{array}{l}\text { Cutoff } \\
\text { Level } \\
(\mathrm{cm})\end{array}$} & \multicolumn{8}{|c|}{ Women } \\
\hline & \multicolumn{4}{|c|}{ Overweight } & \multicolumn{4}{|c|}{ Obese } \\
\hline & $\begin{array}{l}\text { Sen- } \\
\text { sitivity } \\
\text { (\%) }\end{array}$ & $\begin{array}{l}1- \\
\text { Speci- } \\
\text { ficity } \\
(\%)\end{array}$ & $\begin{array}{l}\text { PPVI } \\
\text { NPV }\end{array}$ & $\begin{array}{l}\text { Accu- } \\
\text { racy } \\
(\%)\end{array}$ & $\begin{array}{l}\text { Sen- } \\
\text { sitivity } \\
(\%)\end{array}$ & $\begin{array}{l}1- \\
\text { Speci- } \\
\text { ficity } \\
(\%)\end{array}$ & $\begin{array}{l}\text { PPVI } \\
\text { NPV }\end{array}$ & $\begin{array}{l}\text { Accu- } \\
\text { racy } \\
(\%)\end{array}$ \\
\hline 30.5 & 99 & 97 & 0.71 & 51 & 100 & 97 & 0.54 & 51 \\
\hline 31.5 & 96 & 94 & 0.84 & 51 & 100 & 94 & 0.55 & 53 \\
\hline 32.5 & 88 & 88 & 1.00 & 50 & 98 & 88 & 0.61 & 55 \\
\hline 33.5 & 74 & 78 & 1.07 & 48 & 96 & 78 & 0.65 & 59 \\
\hline 34.5 & 63 & 71 & 1.07 & 46 & 93 & 71 & 0.70 & 61 \\
\hline 35.5 & 53 & 61 & 1.03 & 46 & 88 & 61 & 0.77 & 64 \\
\hline 36.5 & 45 & 52 & 1.00 & 46 & 84 & 52 & 0.83 & 66 \\
\hline 37.25 & 40 & 42 & 0.99 & 49 & 76 & 42 & 0.91 & 67 \\
\hline 37.75 & 40 & 42 & 0.99 & 49 & 75 & 42 & 0.91 & 67 \\
\hline 38.25 & 33 & 33 & 1.00 & 50 & 66 & 33 & 1.00 & 66 \\
\hline 39.5 & 28 & 27 & 1.01 & 51 & 54 & 27 & 1.09 & 64 \\
\hline 40.5 & 23 & 22 & 1.01 & 50 & 44 & 22 & 1.15 & 61 \\
\hline 41.5 & 19 & 18 & 1.01 & 50 & 38 & 18 & 1.19 & 60 \\
\hline 42.5 & 14 & 14 & 1.02 & 50 & 31 & 14 & 1.25 & 59 \\
\hline 43.5 & 11 & 12 & 0.98 & 50 & 25 & 12 & 1.26 & 57 \\
\hline 44.5 & 9 & 8 & 1.03 & 50 & 21 & 8 & 1.33 & 56 \\
\hline 45.5 & 7 & 5 & 1.15 & 51 & 15 & 5 & 1.42 & 55 \\
\hline 46.5 & 5 & 4 & 1.08 & 50 & 11 & 4 & 1.41 & 54 \\
\hline 47.5 & 3 & 3 & 0.91 & 50 & 8 & 3 & 1.39 & 52 \\
\hline 48.5 & 1 & 2 & 0.79 & 50 & 5 & 2 & 1.42 & 52 \\
\hline 49.5 & 1 & 1 & 0.83 & 50 & 4 & 1 & 1.48 & 51 \\
\hline 50.5 & 1 & 1 & 0.83 & 50 & 3 & 1 & 1.41 & 51 \\
\hline 51.5 & 1 & 1 & 1.08 & 50 & 2 & 1 & 1.54 & 51 \\
\hline 52.5 & 0 & 0 & 1.03 & 50 & 1 & 0 & 1.51 & 50 \\
\hline
\end{tabular}

\section{Discussion}

Different body morphologies or types of fat distribution are related to the health risks associated with obesity. Neck circumference (NC) has been proposed as a useful indicator to measure upper body obesity in different studies in the past [3, 14-18]. These studies have shown that men with $\mathrm{NC}<37 \mathrm{~cm}$ and women with $\mathrm{NC}<34 \mathrm{~cm}$ have a low body mass index [14].

BMI and WC are indices of general and central (visceral) obesity respectively, and are an important first step in determining the level and distribution of obesity [19]. BMI is a reasonable index of fatness because it is simple, easy to determine, inexpensive, safe, and practical. It has shown reasonably good correlation with the direct measures of fatness [20]. It is age and sex dependent when used as an indicator of body fatness, although it is ethnicity independent in black and white adults [21]. BMI should be used to assess overweight and obesity and to monitor changes in body weight [1].

The cutoff values of WC for overweight and obesity vary widely over different geographic regions of the world. Furthermore, for WC, 'underweight' and 'normal weight' has not been properly defined as there has been no mention in the literature of the lower limit of normal WC. Therefore, in this study overweightand obesity-related variables were compared primarily with BMI values.

The current research suggests the potential value of measuring NC as an indicator of overweight and obesity. The method has been around for a while, but not utilized due to lack of proper research. So, the present research is planned to determine if $\mathrm{NC}$ is a valid measure of obesity in our population, because NC measurement potentially has distinct cultural advantages. Due to cultural inhibitions measurement of hip, thigh or waist circumference is cumbersome in females. The specific research questions for this research are two-fold: one, to determine the reliability of NC as a measure of obesity as compared to BMI or WC or waist/hip ratio; and, two, to identify the cutoff points for overweight and obesity for adults using NC.

The results show a strong positive correlation of $\mathrm{NC}$ with BMI and WC in both male and female subjects. This study indicates that NC was associated with age, weight, waist and hip circumferences, waist/hip ratio, and BMI for men and women. Thus, a strong association was found between NC and conventional overweight and obesity indices. An evaluation of subjects who were defined as false positive or false-negative did not disclose any significant pathology, including soft tissues, bones and muscles in the neck region, or any other disease, for example, hypothyroidism, which may have influenced the association between NC and overweight or obesity.

$$
\text { Various indices predict specifically }
$$


intraabdominal fat, cardiovascular risk factors, and disease. These include waist/hip circumference ratio [22- 24], waist circumference [25, 26], abdominal sagittal diameter $[25,27]$, the ratio of waist:thigh circumference, and the ratio of waist:height or the conicity index [27]. NC used in combination with other measurements in a three-compartment model of interpretable anthropometry separates the effects of visceral adipose tissue mass, subcutaneous adipose tissue mass, and subcutaneous adipose tissue distribution on metabolic parameters under crosssectional and longitudinal conditions $[7,28]$ is also related to cardiovascular risk factors in severely obese men and women [6]. It seems, therefore, that with an increase in NC, the likelihood of risk factors for cardiovascular disease also increases.

$\mathrm{NC}>38.25 \mathrm{~cm}$ for men and $>36.25 \mathrm{~cm}$ for women were the best cutoff levels for determining the subjects with BMI $\geq 25 \mathrm{~kg} / \mathrm{m}^{2}$, using ROC analysis with $83 \%$ sensitivity, $60 \%$ specificity, $0.86 \mathrm{PPV} / \mathrm{NPV}$, and $72 \%$ accuracy for men, and $76 \%$ sensitivity, $55 \%$ specificity, $0.90 \mathrm{PPV} / \mathrm{NPV}$, and $65 \%$ accuracy for women (Table 4,5 ). While $\mathrm{NC} \geq 40.25 \mathrm{~cm}$ for men and $\geq 37.25 \mathrm{~cm}$ for women were the best cutoff levels for determining subjects with $\mathrm{BMI} \geq 30.0 \mathrm{~kg} / \mathrm{m}^{2}$ using ROC analysis, with $79 \%$ sensitivity, $83 \%$ specificity, 1.03 PPV/NPV, and $81 \%$ accuracy were found for men and $79 \%$ sensitivity, $63 \%$ specificity, 0.91 PPV/NPT, and $71 \%$ accuracy for women. These findings indicate that NC can be used as a simple, easy to perform, quick test that can be used to identify overweight or obese patients. Although NC shows a strong correlation with both overweight and obesity, it is reasonable to consider it as a screening test. Men with $\mathrm{NC}$ less than $38.25 \mathrm{~cm}$ and women with $\mathrm{NC}$ $36.25 \mathrm{~cm}$ do not require additional evaluation. Patients above these levels require a more comprehensive evaluation of their overweight or obesity status.

Strengths and limitations. This study adds to the current literature by showing that neck circumference is a correlate of obesity and overweight. Since obesity is not just limited to urban and affluent society but also affects the rural places and persons belonging to the lower socio-economic strata. US preventive service task force recommends that all adults must be screened for obesity to prevent morbidity and mortality. And screening must be simple, least cumbersome, noninvasive and easily feasible like measurement of neck circumference. In the current research data were collected from Big Cairo area, 6 October City and Giza Governorates including both urban and rural areas with different socioeconomic strata. The limitation is that neck circumference is a proxy for upper-body fat; we did not have radiographic measures to directly quantify this fat deposition.

Implications for further research. Upper-body fat deposition as in neck circumference is less cumbersome, easily measured fat depot, which may be an important predictor of obesity and overweight ultimately leading to preventable risk like diabetes, hypertension and metabolic syndrome. This fat depot may lead to a better understanding of the differential effects of adiposity in men and women. However further studies are needed to examine the relationship between neck circumference and obesity in community setting and their correlations with obesity co morbidities like cardio metabolic complications.

Conclusion: NC measurement is a simple and timesaving screening measure that can be used to identify overweight and obese adults. Using BMI and WC as standards for obesity grading, men with NC $38.25 \mathrm{~cm}$ and women with NC $36.25 \mathrm{~cm}$ are considered to be overweight. Adults with NC $40.25 \mathrm{~cm}$ for men and $37.25 \mathrm{~cm}$ for women are considered to be obese. So, Men with NC $>38 \mathrm{~cm}$ and women with NC $>36 \mathrm{~cm}$ require additional evaluation of overweight or obesity status.

\section{Acknowledgment}

Authors are greatly thankful to the Science and Technology Development Fund (STDF) for funding the project entitled "Standardization of Adult Egyptian Dimensions for Implementation in Development of Clothing Industries" (1256) that enabled us to use the data to establish this work.

\section{References}

1. Expert Panel on the Identification, Evaluation, and Treatment of Overweight in Adults. Clinical guidelines on the identification, evaluation, and treatment of overweight and obesity in adults: executive summary. Am J Clin Nutr. 1998; 68:899-917.

2. Egypt Demographic and Health Survey, Nutritional status. Chapter 14, 2008:185-188.

3. Hingorjo MR, Qureshi MA, Mehdi A. Neck circumference as a useful marker of obesity: A comparison with body mass index and waist circumference. JPMA. 2012;62: 36-40.

4. Vague J. The degree of masculine differentiation of obesities: a factor determining predisposition to diabetes, atherosclerosis, gout, and uric calculous disease. Am J Clin Nutr. 1956;4: 20-34.

5. Kissebach AH, Vydelinqum N, Murray R, Evans DJ, Hartz AJ. Relation of body fat distribution to metabolic complications of obesity. J Clin Endocrinol Metab. 1982;54: 254-60.

6. Sjostrom CD, Håkangård $A C$, Lissner L, Sjostrom L. Body compartment and subcutaneous adipose tissue distributionrisk factor patterns in obese subjects. Obes Res. 1995;3: 922.

7. Sjostrom CD, Lissner L, Sjostrom L. Relationship between 
changes in body composition and changes in cardiovascular risk factors: the SOS Intervention Study: Swedish obese subjects. Obes Res. 1997;5:519-30.

8. Jensen MD. Lipolysis: contribution from regional fat. Annu Rev Nutr. 1997;17:127-39

9. Hiernaux, J. and J.M. Tanner, 'Growth and physical studies', In J.S. Weiner, S.A. Lourie (Eds.), Human Biology: A guide to field methods. London: IBP; Oxford, UK: Blackwell Scientific Publications, 1969.

10. Lean ME, Han TS, Morrison CE. Waist circumference for indicating need for weight management. Br Med J. 1995;311: 158-61.

11. Casimirri F, Pasquali R, Cesari MP, Melchionda N, Babara L. Interrelationships between body weight, body fat distribution and insulin in obese women before and after hypocaloric feeding and weight loss. Ann Nutr Metab. 1989; 33:79-87.

12. Den Besten C, Vansant G, Weststrate JA, Deurenberg P. Resting metabolic rate and diet induced thermogenesis in abdominal and gluteal femoral obese women before and after weight reduction. Am J Clin Nutr. 1988;47:840 -7.

13. Kanaley JA, Andersen-Reid M, Oenning L, Kottle BA, Jensen MD. Differential health benefits of weight loss in upper-body and lower body obese women. Am J Clin Nutr. 1993;57:20-6.

14. Ben-Noun L, Sohar E, Laor A. Neck circumference as a simple screening measure for identifying overweight and obese patients. Obes Res. 2001; 9: 470-7.

15. Ben-Noun L, Laor A. Relationship of neck circumference to cardiovascular risk factors. Obes Res. 2003; 11: 226-31.

16. Ben-Noun LL, Laor A. Relationship between changes in neck circumference and changes in blood pressure. Am J Hypertens. 2004; 17: 409-14.

17. Ben-Noun LL, Laor A. Relationship between changes in neck circumference and cardiovascular risk factors. Exp Clin Cardiol. 2006; 11: 14-20.

18. Kumar S, Gupta A, Jain S. Neck circumference as a predictor of obesity and overweight in rural central India. Int J Med Public health. 2012;2(1):62-66.

19. Janssen I, Heymsfield SB, Allison DB, Kotler DP, Ross R. Body mass index and waist circumference independently contribute to the prediction of nonabdominal, abdominal subcutaneous, and visceral fat. Am J Clin Nutr. 2002; 75: 6838.

20. Ashwell M. Obesity in men and women. Int $\mathrm{J}$ Obes Relat Metab Disord. 1994;18(suppl 1):S1-S7.

21. Gallagher D, Visser M, Sepulveda D, Pierson R, Harris T, Heymsfield SB. How useful is body mass index for comparison of body fatness across age, sex, and ethnic groups? Am J Epidemiol. 1996;143:228 -39.

22. Lapidus L, Bengtsson C, Larsson B, Pennert K, Rybo E, Sjo"sto"m L. Distribution of adipose tissue and risk of cardiovascular disease and death: a 12-year follow up of participants in the population study of women in Gothenburg, Sweden. Br Med J. 1984;289:1257-61.

23. Larsson B, Sva"rdsudd K, Welin L, Wilhelmsen L, Bjo"rntorp $P$, Tibblin G. Abdominal adipose tissue distribution, obesity and risk of cardiovascular disease and death: 14-year follow-up of participants in the study of men born in 1913. Br Med J. 1984;288:1401- 4 .

24. Ashwell M, Cole TJ, Dixon AK. Obesity: new insight into anthropometric classification of fat distribution shown by computed tomography. Br Med J. 1989;290:1692- 4.

25. Pouliot MC, Despres JP, Lemieux S, Moorjani S, Bouchard C, Tremblay A. Waist circumference and abdominal sagittal diameter: best simple anthropometric indexes of abdominal visceral adipose tissue accumulation and related cardiovascular risk in men and women. Am J Cardiol. 1994;73: 460-8.

26. Han TS, van Leer EM, Seidell JC, Lean MEJ. Waist circumference action levels in identification of cardiovascular risk factors: prevalence study in a random sample. $\mathrm{Br}$ Med $\mathrm{J}$. 1995;311:1401-5.

27. Seidell JC, Flegal KM. Assessing obesity: classification and epidemiology. Br Med Bull. 1997;53:238 -52.

28. Yang GR, Yuan SY, Fu HJ, Wan G, Zhu LX, Bu XL, et al; Beijing ,Community Diabetes Study Group. Neck circumference positively related with central obesity, overweight, and metabolic syndrome in Chinese subjects with type 2 diabetes: Beijing Community Diabetes Study 4.Diabetes Care. 2010; 33: 2465-7. 